\title{
Disaster Recovery in Social Aspect: Evidence from Lombok Earthquake 2018
}

\author{
Mala Mardialina ${ }^{1},{ }^{*}$ Ahmad Mubarak Munir ${ }^{2}$ \\ ${ }^{1}$ Department of International Relations, University of Mataram \\ ${ }^{2}$ Department of International Relations, University of Mataram \\ Email: mubarakmunir44@gmail.com
}

\begin{abstract}
This study aims to describe the recovery of the social sector in Lombok after the 2018 earthquake. Using a disaster recovery analysis framework and social capital to detect the potential of the people of Lombok through the efforts of the National Disaster Management Agency (BNPB) in the process of activating community-based social capital. Social sector recovery is carried out by providing assistance to 6 subsectors, namely; education, religion, youth, arts, and health. The role of social institutions and the existence of Tuan guru become catalysts to support the process of social recovery in Lombok society. Using a qualitative approach, data collection techniques were carried out by literature study, interviews, and group observations.
\end{abstract}

Keywords: social capital, earthquake, disaster, social recovery, tuan guru.

\section{INTRODUCTION}

The earthquake in 2018 was a severe disaster that befell the people of the island of Lombok in the last 40 years. Earthquakes with a fairly high frequency for approximately three months make quite significant changes to society. Offices and schools were closed, economic activity was paralyzed, people were afraid to move inside their homes, so they built emergency tents. This phenomenon is the impact of the earthquake other than the damage to public facilities and infrastructure.

The island of Lombok was rocked by series of large earthquakes in the period of July-August 2018, the largest earthquake with a magnitude of 7 occurred on 5 August 2018 which was previously preceded by a 6.4 magnitude earthquake on 29 July 2018 in North Lombok Regency and series of aftershocks with average strength 6 magnitude occurred until the end of 2018.[1] The National Disaster Management Agency (BNPB) noted 
that the total number of casualties reached 564 people with injuries reaching 1,584 people and 390,592 people were displaced. This earthquake also caused damage to health facilities, the economy, houses of worship, and other public facilities with a total loss of up to 12 trillion.[2]

The government has set an emergency response to ensure the progress of a rapid assessment of the number of victims, damage, and other service disruptions as a result of the earthquake. This process then continued with Presidential Instruction (Inpres) Number 5 of 2018 concerning the Acceleration of Post-Earthquake Rehabilitation and Reconstruction in West Lombok, North Lombok, Central Lombok, East Lombok, Mataram City, and affected areas in West Nusa Tenggara Province. This Presidential Instruction (Inpres) regulates the involvement of 19 ministries to participate in the post-earthquake rehabilitation and reconstruction process on the island of Lombok. Rehabilitation refers to this Inpres refers to 9 important points, among others: Improvement of the disaster environment; Repair of public infrastructure and facilities; Providing assistance for community housing repairs; Psychological social recovery;
Health services; Social, economic, and cultural recovery; Restoration of security and order; Restoration of government functions; and Restoration of public service functions. [3]

Reconstruction includes several important things, among others; Rebuilding infrastructure and facilities; Rebuilding community social facilities; Revival of the socio-cultural life of the community; Applying proper design and use of better and disaster-resistant equipment; Participation and participation of social institutions and organizations, the business world, and the community; Improvement of social, economic and cultural conditions; increasing the function of public services; and Improvement of primary services in the community. This Presidential Instruction became the basis for rehabilitation and reconstruction after the 2018 Lombok earthquake. [3]

During the 2018-2020 period, at least the government has made efforts to reconstruct and rehabilitate earthquake victims. The construction of houses for earthquake victims reached 61,000 houses consisting of mild to heavily damaged houses - construction of public facilities and social facilities with a total of 225,000 buildings that have been built. The government through BNPB 
has issued a building reconstruction fund of 5.1 trillion with direct community involvement through orders from facilitators and the Indonesian National Army [4]

The post-earthquake rehabilitation process is one of the important stages in building the social life of the community after a disaster. Building the social life of the community after a disaster is closely related to the social capital that the community has. Social capital will determine the significance of the emergence of a community from adversity due to disasters, the activeness, and creativity of the community in fostering the spirit of building a better life play a very important role [5]

This research will try to explore how post-disaster recovery efforts launched by the government by focusing on the analysis of social capital owned by the people of Lombok. Disaster Recovery is understood to be limited to building a physical building known as reconstruction. The government often forgets to rebuild human resources which constitute a social society. Human development is important to be empowered in strengthening communities to participate in facing various disasters in the future. Community participation is a necessity in reducing disaster potentials or in other words, involving the community in the process of disaster mitigation towards a disaster-resilient community.

\section{RESEARCH METHOD}

This is qualitative research conducted in Lombok Island. The data in this research were obtained through interviews, books, journals, government documents, and online media. The dynamics of some community and the government's disaster recovery strategies becomes analysis tools in this research.

\section{SOCIAL CAPITAL AND DISASTER}

Post-disaster recovery is an important part for policymakers to encourage the creation of better and more independent community living. The disaster has destroyed the socio-economic sector of society so that a scheme is needed to revive the socio-economic activity. With regard to post-disaster recovery efforts, there are common perceptions at both the global and regional levels. The Sendai Framework or Sendai Framework 2015-2030 is one of the global commitments in building disaster mitigation globally - signed in Sendai, Miyagi, Japan on 14-18 March 2015. The framework itself is a continuation of the Hyogo Framework for Action 
which emphasizes building resilience to disasters. [6]

The framework itself aims at substantially reducing the risk and loss of life due to disasters, livelihoods, and health as well as economic, physical, social, cultural, and environmental assets of every person, businessman, community, and country. There are four priorities in the framework alone, among others; a) understand disaster risks; b) strengthening disaster risk governance to manage disaster risk; c) investing in disaster risk reduction for resilience; d) Enhancing disaster preparedness for an effective response and for "building back better" in recovery, rehabilitation, and reconstruction. In the process of disaster risk reduction, each actor is expected to be directly involved and build cooperation by considering their capacities and capacities [6]

Post-disaster recovery becomes a global agenda through its own framework, this shows the seriousness of the international community in responding to disasters that occur. One of the strategies in post-disaster recovery is the social capital approach. The World Bank defines Social Capital as something that refers to the institutional dimension, the relationships that are created, and the norms that shape the quality and quantity of social relations in society. Francis Fukuyama gives an understanding of social capital as a set of informal values or norms that spread among group members that allow cooperation to occur among them.[7] A different definition was put forward by Eva Cox, who considers social capital as a series of human relations processes that are supported by social networks, norms, and beliefs that enable efficient and effective coordination and mutual benefits [8]

Social capital, in general refers to the trust, social norms, and networks which affect social and economic activities [9] Some researchers have seen the link between the recovery of the social conditions of the community, and social capital after a disaster. One of them is the recovery of the social and economic conditions of the Lombok people by activating their social capital. One form of social capital in Lombok society, especially Gondang Village, North Lombok, has a tradition of being the capital to recover after an earthquake. These traditions include Sangkep (deliberation); Ngibukang (mutual cooperation); Nembakuh (cooperation to build houses).[10] Sangkep as one of the social capital of the Gondang community is a 
term used in gathering people to seek a consensus. The availability of the community to gather and discuss shows that they have a high enough level of trust with others. The second capital of ngibukang is understood as the cohesiveness of the community in doing something together. Cooperating in completing work is deeply rooted in the Gondang community. In the process of building emergency tents and even in the construction of temporary shelters, the community cooperatively works hand in hand in development. Furthermore, nembakuh is also understood as the ability to work together, but more specifically cooperation is working together in building houses. In the reconstruction process, nembakuh has become visible asset as a catalyst for the rise of the Gondang community.[10] The government, through the National Disaster Management Agency (BNPB), has realized the social assistance program as a real step in the recovery of the social sector of Lombok society. In collaboration with the University of Mataram as the implementer of social assistance activities.

\section{SOCIAL ASSISTANCE PROGRAM}

The National Disaster Management Agency (BNPB) collaborated with the
University of Mataram in implementing a post-earthquake recovery program in Lombok. The program named the Social Assistance Program (Program Pendampingan Sosial), it was initiated by BNPB with the aim of restoring the social conditions of the community. This program emphasizes the activation of social capital in a community. Activation of social capital in a community is focused on several social subsectors, among others; religion, education, health, socio-culture, social institutions, cultural arts, cultural heritage, youth, and psychosocial.

The religious sector consists of three target groups, the Zikir Zaman, Ratibul Hadaad, and the Quran Education group. There were three groups in culture art, Tari Gegeruk, Klentang, and Gendang Beleq. The last sector was health, and it was assisted in East Lombok, and North Lombok.

This program is implemented in 4 districts by assisting 12 social groups with reference to 9 subsectors. The number of assisted groups is based on the severity of an area, North Lombok and East Lombok being the districts with the highest number of assisted groups. The location of the assistance was determined after going through several stages, starting with a quick assessment process and determining the 
location by involving various related parties.

Social assistance in North Lombok assisted 4 groups consisting of the religious sector, the education sector, and the arts and culture sector. The activities of this group are in the villages of Menggala, and Karang Bajo, which are areas with severe impacts. Then the assistance in East Lombok Regency consists of 4 districts consisting of the sub-sector, education, youth, health, and arts and culture. Sembalun Lawang and Tete Batu Villages are the locations for the assisted groups. West Lombok and Central Lombok districts each received 2 groups of assistance, namely the religious and cultural arts sub-sector, this is because these two districts have no significant impact.[11]

This program has quite a large social impact, it is recorded that at least 495 individuals are directly affected. The greatest achievement was recorded in East Lombok Regency, namely $40.4 \%$, then West Lombok Regency being the lowest. The religious sector is the sector that has benefited the most from this mentoring process, amounting to $34 \%$ and it spread across all districts on the island of Lombok. This program had the greatest impact on women, with
$53 \%$ of the impact of this program being felt by women and the rest on men.[11]

According to BNPB social assistance program data, it is clear how the religious sector becomes the greatest impact and benefits for the community. This is in line with the efforts of religious leaders in encouraging people to rise from disasters. The post-Lombok disaster recovery process is encouraged through various communities that grow and develop in the midst of society.

\section{THE ROLE OF TUAN GURU IN DISASTER RECOVERY AFTER EARTHQUAKE}

The title of tuan guru in Lombok has a long history, dating back to well before Indonesia was formed as a state. They are an important figure in the Sasak/Lombok people, has a high social class and a religious leader who has a broad influence on socio-politics.[12] Tuan guru has various authorities, such as being a spiritual leader, community leader, and political leader.[13] Tuan guru should restore their authority and reputation as Islamic religious scholars with extensive and in-depth expertise. Tuan guru is also synonymous with followers who are referred to as jama'ah, not all of tuan guru have student (santri) and Islamic boarding school lodges like Kiyai in Java. Tuan 
guru's bond with jama'ah then encourages a close and deep relationship, the jama'ah will obey his orders as religious leaders as well as role models in social life. [14] Religious leader in the study of social capital is considered as capital itself. Tuan guru's ability to influence the public be a distinct advantage, the public will be more easily managed and directed.

The other roles of tuan guru can be seen in political aspect, their ability to attract peoples become big asset to maintain their influence. The involvement of some tuan guru in politics has indirect benefits in shaping and engaging the community.[12] Tuan guru who becomes the head of the region will be able to encourage the stability of the post-disaster community. In the context of disaster recovery, tuan guru has a significant role. With the capital they have, the collaboration between tuan guru and the government are able to organize the community in carrying out the recovery process during and after a disaster. One of the important roles of tuan guru is delivering disaster mitigation messages in each of his lectures. Disaster mitigation messages like this can also be seen on the island of Simeulue, Aceh, through the verse nandong, this verse teaches the community to be safe from smong (tsunami) [15] Tuan guru not only plays a role in conveying mitigation messages to the community after the earthquake, but they also have a role to calm and regulate the community when an earthquake occurs in Lombok.

\section{Conclusion}

The recovery of the social sector after the 2018 earthquake was supported by social capital owned by the people of Lombok. Through the social assistance program from BNPB which is also a catalyst in accelerating the recovery of the social sector in society, this program encourages the activation of social capital in community groups. The recovery of the social sector in Lombok is also supported by the significant role of tuan guru, through various religious activities, tuan guru to disseminate disaster mitigation, remind people to be aware of the dangers of earthquakes, informing basic activities when an earthquake occurs and of course, through their influence tuan guru are able to calm the community during a disaster.

\section{ACKNOWLEDGMENTS}

Thank you to the University of Mataram for funding this research, colleagues who accompanied the discussion and development of this research. I would also like to thank all parties involved in 
completing this research, especially the National Disaster Management Agency (BNPB) and team of Social Assistance Program of University of Mataram.

\section{REFERENCES}

[1] F. Pebrianto, "Ini Data Lengkap Kerusakan Gempa Lombok Versi BNPB," Tempo, 2018. https://bisnis.tempo.co/read/1125319/i ni-data-lengkap-kerusakan-gempalombok-versi-bnpb (accessed Feb. 22, 2021).

[2] Badan Nasional Penanggulangan Bencana, "Info Bencana Lombok," pp. $1-2,2018$.

[3] "Inilah Inpres No. 5/2018 tentang Rehabilitasi dan Rekonstruksi Pasca Gempa Bumi di Lombok," Sekretariat kabinet. https://setkab.go.id/inilahinpres-no-52018-tentang-rehabilitasidan-rekonstruksi-pasca-gempa-bumidi-lombok/ (accessed Feb. 02, 2021).

[4] K. Septia, “47.954 Rumah Korban Gempa Lombok Selesai Dibangun," Kompas.com, 2019. https://regional.kompas.com/read/2019 /06/30/07030371/47954-rumahkorban-gempa-lombok-selesaidibangun. (accessed Feb. 22, 2021).

[5] R. Rijanta; D.R. Hizbaron; M. Baiquni, Modal Sosial dalam Manajemen Bencana. Gadjah Mada University
Press, 2014.

[6] United Nation, Sendai Framework for Disaster Risk Reduction 2015 - 2030. 2015.

[7] M. A. Komalasari, "Kapabilitas Manusia dan Pemanfaatan Modal Sosial dalam Pemberdayaan Masyarakat: Suatu Upaya Mengatasi Kesenjangan," Media Inf. Penelit. Kesejaht. Sos., vol. 43, no. 2, pp. 153 164, 2020.

[8] J. Hasbullah, Social Capital: Menuju Keunggulan Manusia Indonesia. Jakarta: MT United Press, 2006.

[9] Y. Nakagawa and S. Rajib, "Social Capital: A Missing Link to Disaster Recovery," Int. J. Mass Emerg. Disasters, vol. 22, no. 1, pp. 5-34, 2004.

[10] W. F. Zullam, S. Syarifuddin, and M. A. Komalasari, "Modal Sosial Sebagai Strategi Pemulihan Pasca Gempa Di Desa Gondang Kecamatan Gangga Kabupaten Lombok Utara," RESIPROKAL J. Ris. Sosiol. Progresif Aktual, vol. 2, no. 1, pp. 108-122, 2020, doi:

10.29303/resiprokal.v2i1.26.

[11] M. Taqiuddin, Interview with head of Social Assistance Program of National Disaster Management Agency (BNPB). 2021. 
[12] M. S. Anwar, "Dinamika Peran Politik Tuan Guru Di Lombok Era Reformasi," THAQAFIYYAT J.

Bahasa, Perad. dan Inf. Islam, vol. 18, no. 2, pp. 146-171, 2018, [Online].

Available: http://ejournal.uinsuka.ac.id/adab/thaqafiyyat/article/vie w/1313.

[13] Jeremy J. Kingsley, "Peacmakers or Peace-Breakers? Provincial Elections and religious Leadership in Lombok, Indonesia," indonesia, vol. 93, pp. 5382, 2012.

[14] Fahrurrozi, "Tuan guru and social change in Lombok, Indonesia," Indones. Malay World, vol. 46, no. 135, pp. 117-134, 2018, doi: 10.1080/13639811.2018.1452487.

[15] A. N. Gadeng, E. Maryani, and D. Rohmat, "The Value of Local Wisdom Smong in Tsunami Disaster Mitigation in Simeulue Regency, Aceh Province," IOP Conf. Ser. Earth Environ. Sci., vol. 145, no. 1, 2018, doi: 10.1088/1755-1315/145/1/012041. 